Original Article

\title{
Emerging SARS-Cov-2 Infection in a Rapidly Changing World
}

\section{Saeed Dorgaleleh ${ }^{1}$ (D) +, Niloufar Sadat Miri ${ }^{2}$ (i) +, Zahra Hajimohammadi ${ }^{3}$, Farzaneh} Khosravi-bachehmir ${ }^{4}$, Akram Vahidi ${ }^{1}$, Morteza Oladnabi ${ }^{5},{ }^{6},{ }^{7}$ (D) *

1. Student Research Committee, Golestan University of Medical Sciences, Gorgan, Iran

2. Student Research Committee, Babol University of Medical Sciences, Babol, Iran

3. Student Research Committee, Shiraz University of Medical Sciences, Shiraz, Iran

4. Student Research Committee, Tehran University of Medical Sciences, Tehran, Iran

5. Gorgan Congenital Malformations Research Center, Golestan University of Medical Sciences, Gorgan, Iran

6. Stem Cell Research Center, Golestan University of Medical Sciences, Gorgan, Iran

7. Ischemic Disorders Research Center, Golestan University of Medical Sciences, Gorgan, Iran

+ These authors contributed equally to this work

*Correspondence: Morteza Oladnabi, Department of Medical Genetics, School of Advanced

Technologies in Medicine, Golestan University of Medical Sciences, Gorgan, Iran.

Tel: +981732430565

Email: oladnabidozin@yahoo.com

Orchid ID: 0000-0001-7037-5084

Received August 08, $2020 \quad$ Accepted September 09, 2020

\begin{abstract}
Background and objectives: Severe acute respiratory syndrome coronavirus 2 (SARS-CoV-2) is the seventh member of the coronavirus family to infect humans. The coronavirus disease was first identified in late 2019 in Wuhan, China. More than five million people in different countries have been infected with the virus in a matter of months. Although many studies have been done on the molecular immune pathogenesis and genetics of SARS-CoV-2, there is still not enough information about the virus. The purpose of this study is to summarize the latest information on SARS-CoV-2 characteristics, transmission, prevention and management to increase awareness and stop the virus transmission cycle.
\end{abstract}

Conclusion: The incidence of post-tonsillectomy hemorrhage, the methods for its management and the need for re-admission are quite different in different age groups.

Keywords:COVID-19; Corona virus; SARS-CoV-2 


\section{INTRODUCTION}

Over the past 18 years, the world has witnessed three deadly outbreaks of emerging coronaviruses (CoVs), known to cause gastrointestinal and respiratory problems in humans. The first outbreak of severe acute respiratory syndrome (SARS) was caused by SARS-CoV in 2002 in Guangdong, China, which affected 8,098 persons in 37 provinces (1). In 2012, another outbreak called the Middle East Respiratory Syndrome (MERS-CoV) occurred in the Middle East (2). Recently, a new outbreak of coronavirus disease (CoVID-19) appeared in Wuhan, China that spread rapidly around the globe. The causative agent of COVID-19 was first identified in late January 2020 as SARSCoV-2 or 2019-nCoV (3). Severe acute respiratory syndrome coronavirus 2 (SARS-CoV-2) is the seventh member of the CoVs family to infect humans (4). China started to investigate symptomatic patients who had been in close contact with wet markets and declared that the infection may be caused by a new virus. According to the World Health Organization (WHO) report on July 20th, 2020, there are 14,664,054 laboratory-confirmed cases of COVID-19 and 609,279 deaths in 213 countries (5). China, Italy, the United States, Spain and Germany currently have the highest mortality rates (6). The WHO conducted further studies on the virus's genome and concluded that the virus had more than $95 \%$ homology with the $\mathrm{CoV}$ in bats. Although it is assumed that the source of the virus is Rhinolophus affinis species from Yunnan Province, the intermediate animal that could transmit the virus to humans remains unknown (7). Many have reported pangolins to be the main suspects because of $91 \%$ homology between SARSCoV-2 and pangolin-CoV. In addition, the $\mathrm{S}$ protein has a similar structure in both viruses (8). The Coronaviridae family is placed in the Nidovirales order that has two subfamilies namely Coronavirinae and Torovirinae. There are also four groups for
Coronavirinae based on phylogenetic clustering: alpha, beta, gamma and delta CoVs $(9,10)$. The SARS-CoV-2 has a crown like appearance under electron microscope. They are enveloped viruses with a single strand, positive-sense RNA genome with variable GC content, which is the largest known genome for an RNA virus. The RNA genome contains seven genes $(27-31 \mathrm{kB}), 14$ open reading frames (ORFs) that encode 27 proteins. The diameter of this enveloped virus varies between 14-60 nm (11). It has four major structural proteins: the spike surface glycoprotein, small envelope protein, matrix protein and nucleocapsid protein, which is increased in patients with no history of contact with live animals indicating that virus is spread via humanto-human transmission or contaminated surfaces (11). Patients with severe conditions are more contagious than those with mild to moderate symptoms. Asymptomatic patients as well as those in the incubation period with no sign of respiratory infection are potential sources of infection (12). In terms of infection spectrum, the disease is considered as selflimiting and most cases can be cured with mild symptoms in 1-2 weeks (12). The frequency of asymptomatic, mild to moderate, severe and critical cases is estimated to be $1.2 \%, 80.9 \%, 13.8 \%$ and $4.7 \%$, respectively. In addition, there is an estimated $2.3 \%$ mortality rate. Recent studies have shown that the rate of asymptomatic infection in children under 10 years of age is $15.8 \%(13,14)$. Overall, 98\% of patients had bilateral involvement in chest CT scans. Patients with underlying disorders have poor diagnosis and the mortality rate in non-underlying disorders was $0.9 \%$. Moreover, the mortality rate in patients with cardiovascular disease, diabetes, chronic respiratory disease, hypertension and cancer was $10.5 \%, 7.3 \%$, $6.3 \%, 6.0 \%$ and $5.6 \%$, respectively (15). Older people and those with underlying 
diseases like asthma, diabetes, cardiovascular disease and cancer may be more susceptible to the virus, while smoking and obesity are predisposing factors. Those in close contact with the infected individuals including healthcare workers and patients' family members are also at high risk of contracting the virus (16).

\section{Life cycle of SARS-CoV-2 in host cells}

Although many proteins are involved in virus production and host invasion, spike proteins (S protein) are the most important factor in determining host domain. Glycoproteins play an essential role in binding to receptors on host cells, membrane fusion, host tropism, transmission capacity and determining host tissue orientation. The $\mathrm{S}$ protein is a type 1 transmembrane protein with a separable $\mathrm{N}$ terminal peptide signal, a large and heavy actinomycin $\mathrm{n}$, a membrane transregion and a cytoplasmic tail containing a cluster of sacylated cysts. Each monomer teremeric protein is approximately $180 \mathrm{kD}$, which includes two subunits $\mathrm{S} 1$ and $\mathrm{S} 2$. The second S1 carries the binder-receptor activity, and the second protected s2 catalyzes the membrane fusion. The second $\mathrm{S} 1$ is divided into two parts: N-terminal domain (ntd) and C-terminal domain (ctd). Ntd is shown as a structural fold such as human galactin, in order to be a binding factor. The ctd in SARS-CoV and ncov2019 is responsible for binding to angiotensin-converting enzyme 2 (ACE2) receptor and consists of two subdomains: a nuclear structure consisting of a 5-strand antiparallel plate and a real receptor binding motif (RBM) that determines the receiver's connection characteristics. Based on the RBM-ACE2 complex, most $\mathrm{S}$ residues in contact with the ACE2 receptor are shared between SARS-CoV and SARS-CoV-2. However, some are unique including an important salt bridge that contains various amino acids in ACE2 in order to bind to SARS-CoV and SARS-CoV-2. These minor differences may explain the more effective connection of SARS-CoV-2 S protein to ACE2. However, this has not been observed in other preliminary studies.

Variety of receiver usage is a prominent feature of CoVs (assuming they are all derived from a common ancestor) that they have already changed the connection feature of their receiver several times during evolution. Depending on the virus, the second ntd or ctd can act as a receptor binding domain (rbd). Depending on the virus type and the cell type, the spike CoV protein may be synthesized by one or more proteins, including furin, trypsin, cathepsins, transmembrane protease serine protease-2 and -4 or human airway trypsin-like protease. The availability of these proteases on the target cell determines whether CoVs enter the cell through the plasma membrane or endocytosis (17). An important feature of the SARS-CoV-2 is having a polybasic cleavage site where $\mathrm{S} 1$ and $\mathrm{S} 2$ are connected. This feature is important for effective cutting by furin and other proteases to generate S1 and S2 (18). N protein binds to the nucleic acid of the virus; therefore, it plays a role in replication and host response. It seems that phosphorylation of protein $\mathrm{N}$ and structural changes play a role in viral genomes (19). The main structural protein in the virus is $\mathrm{M}$ protein, which binds to $\mathrm{N}$ protein and is involved in its stability and the formation of N-RNA complexes (20). The $\mathrm{N}$ protein is also involved in virus maturation. The largest gene for SARSCoV-2 is ORF1ab, which encodes pplab protein and non-structural proteins (Figure $1)$. 


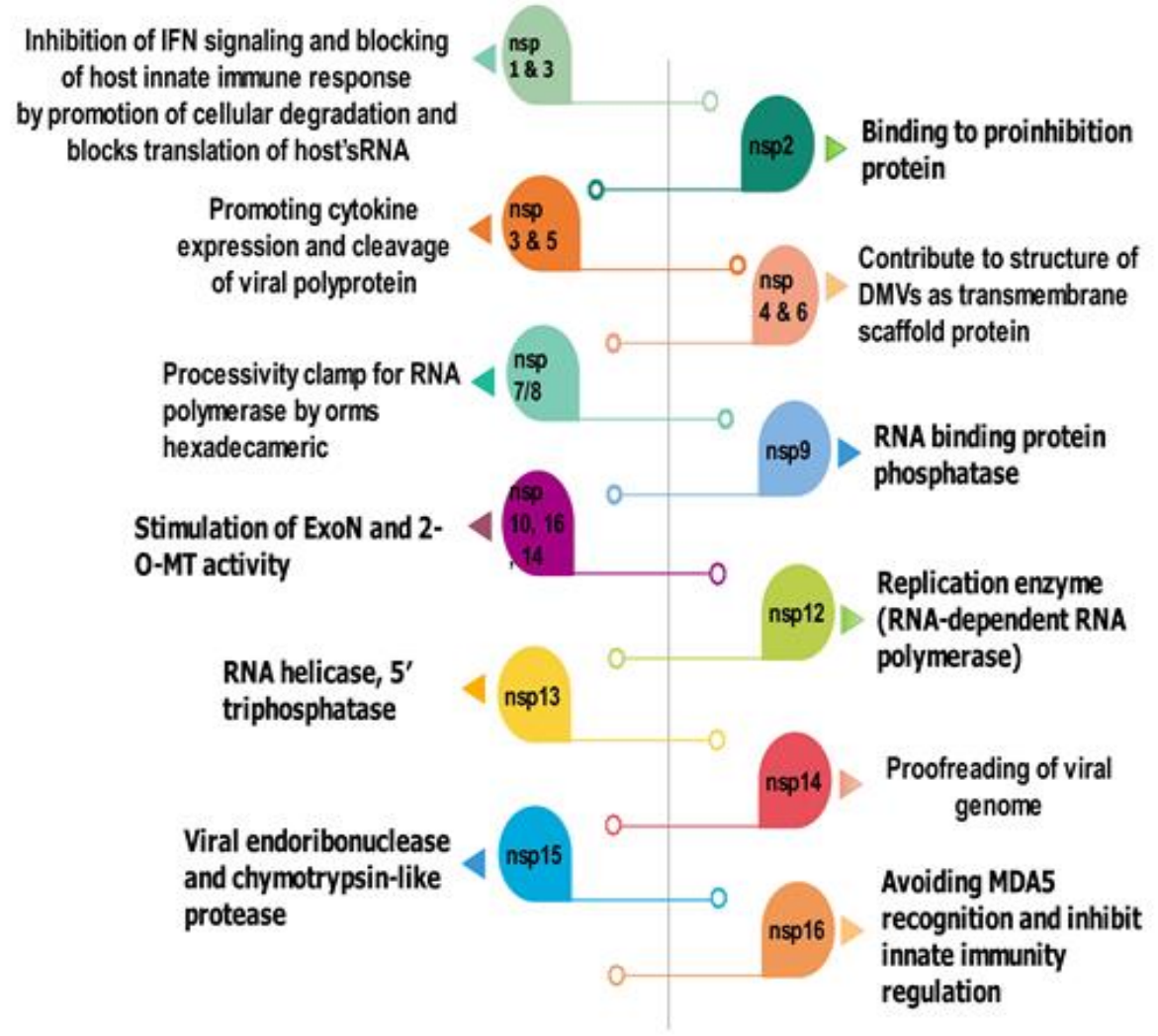

Figure 1. Non-structure proteins (nsps) and their function in coronaviruses. All Figures were drawn using the Edraw Max 10.0.4 software.

Polyproteins are completed by a protein similar to papain and a similar protease encoded by chemotripcin 3clpro (encoded in nsp3 and nsp5). Compared to SARS-CoV, 8a protein is absent and the level of $8 \mathrm{~b}$ and $3 \mathrm{c}$ proteins is higher and lower in SARS-CoV-2, respectively (Figure 2) $(21,22)$. 
genome organization

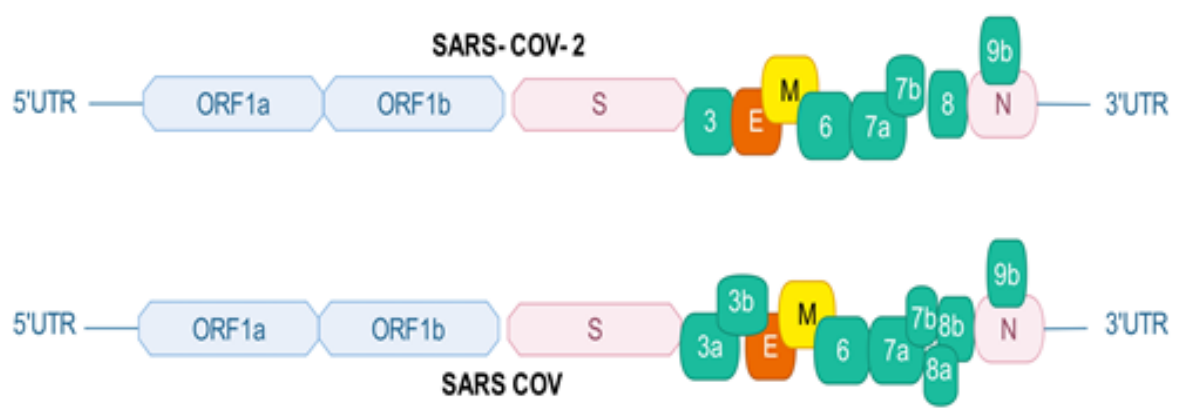

Figure 2. Genome structure in SARS-CoV and SARS-CoV-2

Two important proteins are known to be the main causes of viral penetration: ACE2 and TMPRSS2 (23). As figure 3 illustrates, the binding of glycoprotein $\mathrm{S}$ to the ACE2 receptor in the lower respiratory tract, is the starting point for the virus to enter the host cell (24). It is necessary to connect to the ACE2 receptors, five of which are different between SARS-CoV-2 and SARS-CoV. A mutation (N501T) has been found in the $S$ protein of the virus that increases the binding affinity to the receptor. This binding of the membrane to the host cell and the virus is associated with fusion (25) and activation of the $S$ protein, which changes the conformation and leads to viral entry. The genomic material of the virus is released into the cytoplasm, which can be translated into proteins. Structural and peripheral proteins translated from subgenomic proteins and genomes containing the $\mathrm{N}$ protein are transferred to the endoplasmic reticulum and then to the endoplasmic reticulumGolgi intermediate compartment, forming a complete virus-containing vesicle and exiting the virus by exocytosis $(25,26)$. 


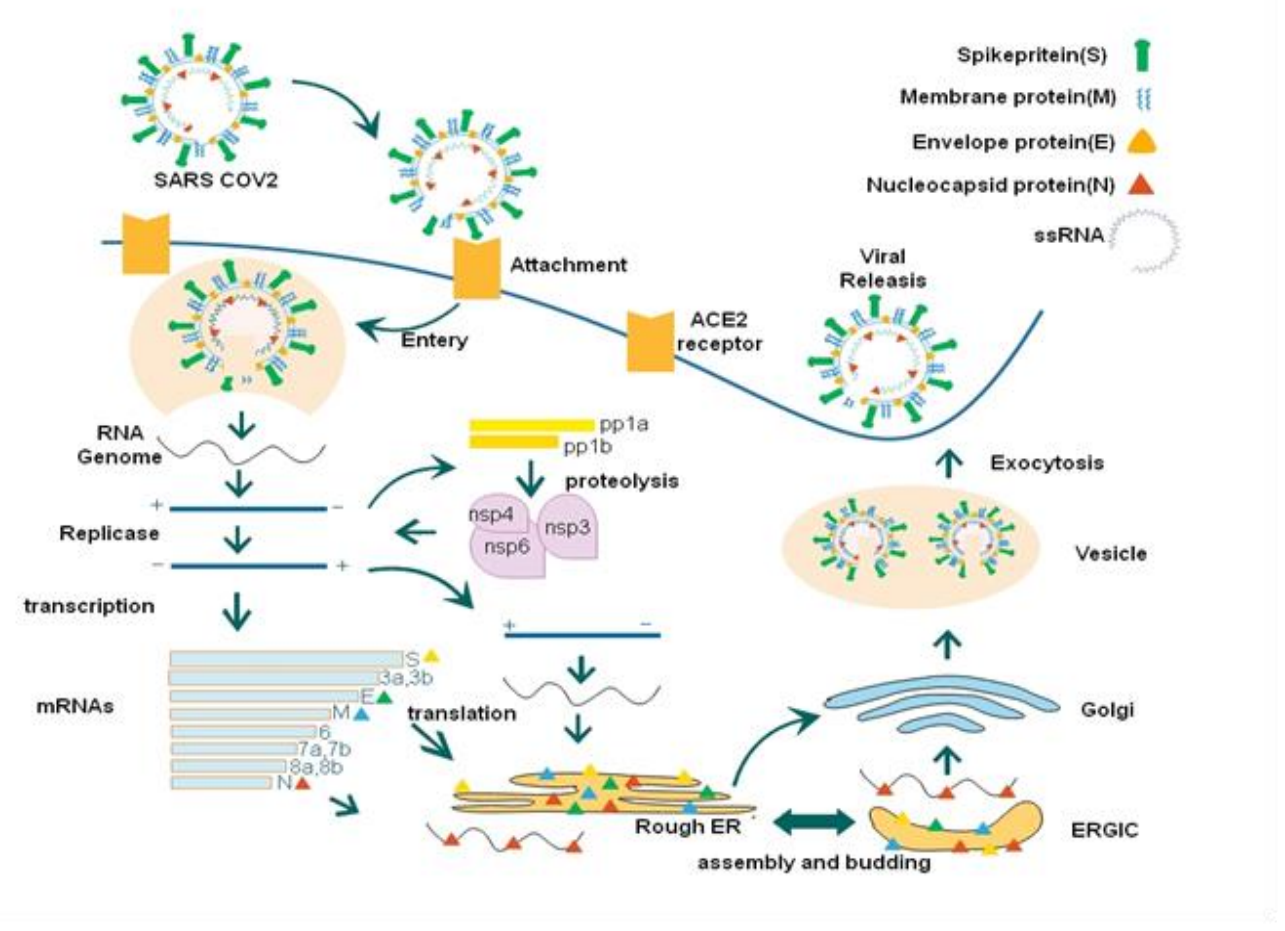

Figure3. SARS-CoV-2 life cycle in host cell.

First, the $\mathrm{S}$ protein binds to the ACE2 receptor, leading to fusion of the viral envelope and the cell membrane. Next, the virus enters the cell via the endosome pathway and the $S$ protein is separated. The virus genome is released into the host cell and translates into $1 \mathrm{a}$ and $1 \mathrm{~b}$ polyproteins. These proteins are broken down by proteases. Genome transcription creates a set of mRNAs. Viral genome and proteins merge into the endoplasmic reticulum and Golgi apparatus and then leave the cell by endocytosis.

\section{The main modes of COVID-19 transmission}

Knowing the routes of transmission is essential for the prevention and control of infectious diseases. Recombination in $\mathrm{S}$ protein has given the virus high transmission capacity compared to influenza and common cold viruses in a way that each COVID-19 patients can spread 1.8-fold more contacts compared to flu patients through infected bodily fluids $(27,28)$. It is important to note that if these infected respiratory droplets are present on surfaces, transmission to new host will become possible. The SARS-CoV-
2 can also be transmitted during asymptomatic periods. It is possible to

prevent the spread of infection and virus transmission through improving our knowledge about hygiene and virus's growth conditions in different conditions. The major route of SARS-CoV-2 transmission is via droplets and close contact. The SARS-CoV2 is believed to be more transmissible than the SARS-CoV (29). Reports suggest that the SARS-CoV-2 can also be detected in urine and feces of patients. However, there is no evidence of virus transmission via consumption of virus-contaminated foods, aerosols or vertical transmission in pregnancy $(30,31)$.

\section{Infection prevention and control for SARS-CoV-2}

The WHO has recommended several ways to prevent the transmission of SARS-CoV-2 virus. First, it is important to use a tissue when coughing and sneezing, or cough or sneeze in the elbow. Governments began 
quarantining people in their homes as the best and safest way to control the virus (32). People with mild symptoms should isolate themselves and stay at home, especially if they have a fever above $37.8{ }^{\circ} \mathrm{C}$ and persistent cough. It is recommended that people do not go to hospitals and pharmacies and stay at home for 14 days. The following steps should be taken to prevent infection and reduce virus transmission: wash hands regularly with soap and water for at least 20 seconds, or soak and rub hands in alcohol, keep at least 2 meters distance from others, avoid unnecessary trips, stay away from large groups of people and follow government guidelines (32).

\section{Clinical management of COVID-19}

There is currently no specific vaccine or treatment for the SARS-CoV-2 virus, although a number of clinical trials are being carried out. Asymptomatic patients as well as those with mild clinical symptoms do not need to be hospitalized. Although clinical signs and symptoms may worsen in the second week of the illness, all patients should be closely monitored for any changes in their vital signs, oxygen saturation, respiratory rate, blood pressure, pulse and blood glucose levels (33). Intense COVID19 management with oxygen therapy is one of the recommendations of the WHO. Plasma therapy is one of the ways to control the COVID-19 pandemic (34). Although anti-parasitic drugs such as chloroquine and hydroxychloroquine have been approved by the US Food and Drug Administration to be tested against the SARS-CoV-2 virus, their administration should be closely monitored due to side effects. In addition, there are some other anti-inflammatory drugs and vaccine that are currently under testing (34).

\section{Effects of temperature and humidity on SARS-CoV-2}

Like many other viruses, SARS-CoV-2 is thought to be sensitive to heat and humidity, which can inactive or reduce transmission to some extent. Temperature has a huge impact on the SARS-CoV-2 spread, while research suggests that warm and wet climates reduce the transmission of the virus (35). According to a systematic study, very hot, very cold and also warm and wet weather prevent the SARS-CoV-2 activity. Based on the information on SARS-CoV-1 and MERS$\mathrm{CoV}$, it is assumed that SARS-CoV-2 could become inactivated in warm and wet climates (35).

\section{Survival of SARS-CoV-2 on different surfaces}

In addition to person-person transmission, contact with contaminated surfaces can also cause SARS-CoV-2 infection. However, sterilizing surfaces can eliminate the virus. As shown in figure 4 , the half-life of the virus on plastic and stainless steel is higher than that on other surfaces such as wood and copper. Moreover, the half-life of the virus in aerosols is about 90 minutes (29). 


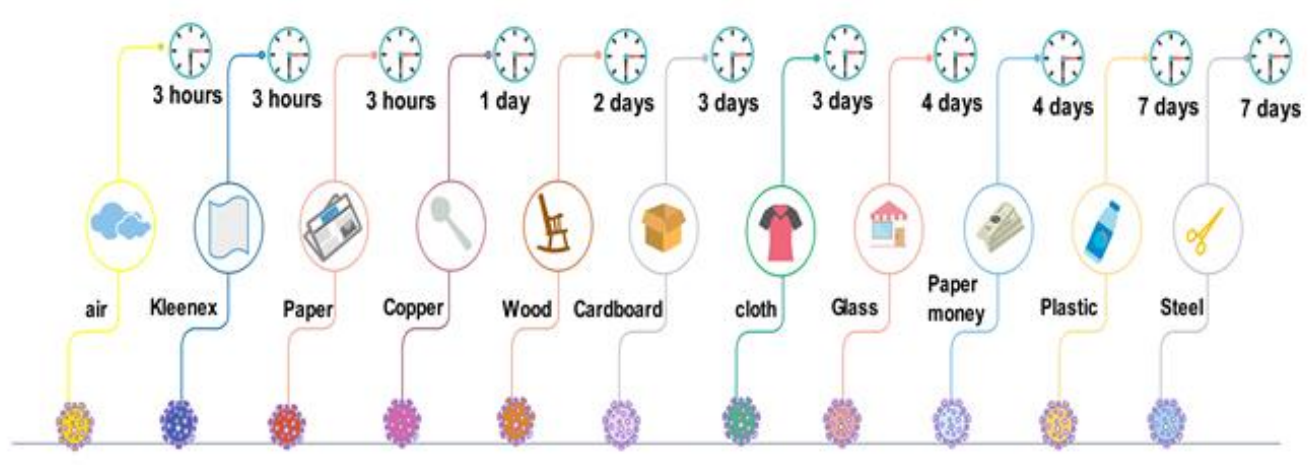

Figure 4. Stabilization time of the SARS-CoV-2 on different surfaces at room temperature

\section{Signs and symptoms of COVID-19 infection}

According to the WHO, pyrexia is the most common symptom (36). Although coughing is a common symptom, sputum is less common in patients. COVID-19 is very similar to flu and common cold in terms of clinical presentation, but it can be distinguished by certain features. For example, rhinorrhea and nasal congestion are frequent in common cold (37). Gastrointestinal-related symptoms include nausea, diarrhea, and vomiting (38). The most important complication of COVID-19 is lung damage, which affects older people and those with underlying disease. It should be noted that anosmia and ageusia are common in almost two third of patients because the virus can cause neuronal brain damage via the olfactory nerve. On the other hand, olfactory dysfunction has been considered as a marker of COVID-19 (39, 40). Other common symptoms of the disease include muscle pain and chills (41). The average age of people affected with the COVID-19 is 47 years with an estimated 2$3 \%$ mortality rate. The risk of developing COVID-19 is directly related to factors such as hypertension, diabetes, respiratory disease and cardiovascular disease (36). It has been also suggested that the level of ACE2 expression in different human tissues may be an important determinant of susceptibility, symptoms and outcome of COVID-19. The RBD binds to the ACE2 receptor present in the heart, lungs, kidneys and gastrointestinal tract, thus facilitating the entry of the virus into the target cells. Children under the age of 14 are at lower risk of contracting the infection since they have lower ACE2 receptor expression level compared to those over 60 years of age and smokers. Of course, this difference in ACE2 receptor expression can also be affected by geographical locations as the receptors is overexpressed in Asians.

\section{Diagnostic testing and screening for SARS-CoV-2}

Due to the fact that COVID-19 is a new pandemic, there is no specific diagnostic test. After complete sequencing of the viral genome on January 12, 2020, it became possible to setup a real-time PCR test with almost $80 \%$ sensitivity. The test can be performed using respiratory samples such as sputum and throat swab. Given the relatively low sensitivity and long duration of the realtime PCR test, chest CT-scan is performed to confirm COVID-19 in hospitals (42). This test is more sensitive (95\%) and specific because it can illustrate infiltrates, ground glass opacities and sub-segmental consolidation (43). Repeating the real-time 
PCR testing increases the chance of correct diagnosis. It should be noted that X-ray is not sensitive enough to be used for the diagnosis of COVID-19. Serological antibody testing can also be a good diagnostic tool for the detection of the infection. In this regard, it has been shown that combined IgM-IgG testing has a high sensitivity for rapid screening for the COVID-19 (44). Other highly sensitive diagnostic methods based on nucleic acid amplification include loop-mediated isothermal amplification, specific high sensitivity enzymatic reporter unlocking and CRISPR-Cas12 (45, 46).

\section{Routine laboratory tests}

Routine blood tests are usually nonspecific to COVID-19 diagnosis, but there is an increase in C-reactive protein, erythrocyte sedimentation rate, alanine aminotransferase/aspartate transaminase ratio, prothrombin time, creatinine, D-dimer, creatine kinase and lactic acid dehydrogenase level in severe cases. On the other hand, standard blood investigations revealed that most patients with COVID-19 have normal or decreased leucocytes as well as lymphocytopenia. Common clinical laboratory findings include leucopenia and lymphopenia. Half of patients have abnormal liver function with elevated alanine aminotransferase or aspartate aminotransferase. Most patients have abnormal myocardial zymogram, which is accompanied with elevation of creatine kinase and lactate dehydrogenase. Furthermore, most patients show normal serum levels of procalcitonin, but the Creactive protein is above the normal range (47).

\section{Immune responses in COVID-19}

The innate immune system is essential for virus detection. In order to induce a sufficient antiviral inflammatory response, it is essential to activate certain pathways. First, the single stranded RNA of SARSCoV-2 is identified as pathogen-associated molecular pattern by cytosolic receptors such as toll-like receptors, retinoid-inducible gene and melanoma differentiationassociated gene 5. These receptors can initiate inflammatory signals through nuclear factor $\kappa \mathrm{B}$, activator protein 1 and interferon response factor 3 in order to produce inflammatory cytokines and chemokines (48). It is noteworthy that type I interferons ( $\alpha$ and $\beta$ ), which are important in antiviral responses are suppressed by the SARS-CoV-2 (49). Following the innate immune response, in order to have an adoptive immune response, the viral antigenic peptides must be presented to cytotoxic $\mathrm{T}$ lymphocytes by major histocompatibility complex (MHC) or human leukocyte antigen (HLA) in humans on antigen presenting cells (50). The type and manner of antigen presentation to immune cells is crucial for treatment and prevention of infectious diseases. As mentioned, HLA plays a key role in initiating immune responses because the antigen receptors on $\mathrm{T}$ lymphocytes can detect antigen peptides. Therefore, genetic and haplotype diversity can be a significant factor in detection of the virus. According to previous studies, HLA loci polymorphisms affect disease susceptibility. Therefore, HLA loci could be an important candidate for treatment and even prevention of COVID19 (50).

\section{Humoral immunity response}

Humoral and cell-mediated immunity are two components of the adoptive immune system. In the humoral immune response, $\operatorname{IgM}$ and $\operatorname{IgA}$ are the first traceable antibodies in serum, but IgG which is produced against the $\mathrm{N}$ protein can be detected in the serum after 10 days. Nine days after contracting the disease, IgM levels increase, and class switching to $\mathrm{IgG}$ can be identified in about 14 days (44).

\section{Cellular immune response}

In the case of cellular immunity, infection is accompanied with a decrease in $T$ lymphocyte subsets and an increase in the production of inflammatory cytokines that 
has a positive correlation with disease severity. Reduction in $\mathrm{T}$ lymphocytes subsets can be a differential diagnosis for SARS viruses. Interestingly, the cytotoxic $\mathrm{T}$ lymphocytes and CD4+/CD8+ ratio have a meaningful association with the inflammatory condition in COVID-19 patients. The lack of memory cells in COVID-19 is controversial (51). In fact, it is considered an important barrier to vaccination against the disease.

\section{Cytokine and chemokine storm}

Uncontrolled activation of inflammatory pathways and production of cytokines and inflammatory chemokines can damage body organs. Among the important produced cytokines (IFN- $\alpha$, IFN- $\gamma$, IL-1 $\beta$, IL-6, IL-12, IL-18, IL-33, TNF- $\alpha$, TGF $\beta$, etc.), an increased production of chemokines such as CCL2, CCL3, CCL5, CXCL8, CXCL9, and CXCL10 have been reported in inflammatory conditions. In addition, increased activation of markers such as HLA-DR and CD45RO and even IL-2 receptor has been reported in patients with COVID-19 (52). On the contrary, costimulatory molecule CD28, natural regulatory $\mathrm{T}$ cells, dendritic cells and $\mathrm{B}$ cells activation were all decreased in extremely severe patients. The most important complication of COVID-19 is a systemic inflammatory disease called acute respiratory distress syndrome, which is also the main cause of mortality (51).

\section{CONCLUSION}

To date, COVID-19 could be a once-in-acentury pandemic that is affecting millions of people worldwide. Due to the alarming rate of COVID-19 spread, medical professionals are investigating strategies for the diagnosis, management and containment of the disease. Although developing a preventive vaccine is of upmost importance, research is also essential for establishing effective treatment methods, particularly against the resistant strains of the virus.

\section{ACKNOWLEDGMENTS}

The authors would like to express gratitude to the faculty members of the Department of Medical Genetics, School of Advanced Technologies in Medicine, Golestan University of Medical Sciences.

\section{DECLARATIONS \\ Funding \\ Not applicable.}

\section{Ethics approvals and consent to participate \\ Not applicable.}

\section{Conflict of interest}

The author declares that there is no conflict of interest regarding publication of this article.

\section{REFERENCES}

1.Christian MD, Poutanen SM, Loutfy MR, Muller MP, Low DE. Severe acute respiratory syndrome. Clinical infectious diseases. 2004;38(10):1420-7.

https://doi.org/10.1086/420743

PMid:15156481 PMCid:PMC7107873

2.Zumla A, Hui DS, Perlman S. Middle East respiratory syndrome. The Lancet. 2015;386(9997):995-1007.

https://doi.org/10.1016/S0140-6736(15)60454-8

3.Wang C, Horby PW, Hayden FG, Gao GF. A novel coronavirus outbreak of global health concern. The Lancet. 2020;395(10223):470-3. https://doi.org/10.1016/S0140-6736(20)30185-9

4.Zumla A, Chan JF, Azhar EI, Hui DS, Yuen K-Y. Coronaviruses-drug discovery and therapeutic options. Nature reviews Drug discovery.2016;15(5):327.

https://doi.org/10.1038/nrd.2015.37

PMid:26868298 PMCid:PMC7097181

5. Worldmeter, COVID-19 cronavirus pandemis, retrived from: https://www.worldometers.info/coronavirus, (last updated September 14, 2020) 
6.Jin Y, Yang H, Ji W, Wu W, Chen S, Zhang $\mathrm{W}$, et al. Virology, epidemiology, pathogenesis, and control of COVID-19. Viruses. 2020;12(4):372.

https://doi.org/10.3390/v12040372

PMid:32230900 PMCid:PMC7232198

7. Zhou P, Yang X-L, Wang X-G, Hu B, Zhang L, Zhang $\mathrm{W}$, et al. A pneumonia outbreak associated with a new coronavirus of probable bat origin. nature. 2020;579(7798):270-3.

https://doi.org/10.1038/s41586-020-2012-7

PMid:32015507 PMCid:PMC7095418

8. Zhang $\mathrm{T}$, $\mathrm{Wu} \mathrm{Q}$, Zhang $\mathrm{Z}$. Probable pangolin origin of SARS-CoV-2 associated with the COVID-19 outbreak. Current Biology. 2020.

https://doi.org/10.1016/j.cub.2020.03.063

PMid:32315626 PMCid:PMC7169893

9. Adams MJ, Carstens E. Ratification vote on taxonomic proposals to the International Committee on Taxonomy of Viruses (2012). Archives of virology. 2012;157(7):1411-22. https://doi.org/10.1007/s00705-012-1299-6

PMid:22481600 PMCid:PMC7086667

10. Perlman S, Netland J. Coronaviruses postSARS: update on replication and pathogenesis. Nature reviews microbiology. 2009;7(6):43950 .

https://doi.org/10.1038/nrmicro2147

PMid:19430490 PMCid:PMC2830095

11. Li Q, Guan X, Wu P, Wang X, Zhou L, Tong $Y$, et al. Early transmission dynamics in Wuhan, China, of novel coronavirus-infected pneumonia. New England Journal of Medicine. 2020.

12. Bai Y, Yao L, Wei T, Tian F, Jin D-Y, Chen L, et al. Presumed asymptomatic carrier transmission of COVID-19. Jama. 2020;323(14):1406-7.

https://doi.org/10.1001/jama.2020.2565

PMid:32083643 PMCid:PMC7042844

13. Fekrazad R. Photobiomodulation and Antiviral Photodynamic Therapy as a Possible Novel Approach in COVID-19 Management.
Mary Ann Liebert, Inc., publishers 140 Huguenot Street, 3rd Floor New ...; 2020. https://doi.org/10.1089/photob.2020.4868 PMid:32326830

14. Lu X, Zhang L, Du H, Zhang J, Li YY, Qu $\mathrm{J}$, et al. SARS-CoV-2 infection in children. New England Journal of Medicine. 2020. https://doi.org/10.1056/NEJMc2005073

PMid:32187458 PMCid:PMC7121177

15. Zaman S, MacIsaac AI, Jennings GL, Schlaich M, Inglis SC, Arnold R, et al. Cardiovascular disease and COVID-19: Australian/New Zealand consensus statement. The Medical Journal of Australia. 2020:1. https://doi.org/10.5694/mja2.50714

PMid:32734645

16. Driggin E, Madhavan MV, Bikdeli B, Chuich T, Laracy J, Bondi-Zoccai G, et al. Cardiovascular considerations for patients, health care workers, and health systems during the coronavirus disease 2019 (COVID-19) pandemic. Journal of the American College of Cardiology.2020.

https://doi.org/10.1016/j.jacc.2020.03.031

PMid:32201335 PMCid:PMC7198856

17. Jin Z, Du X, Xu Y, Deng Y, Liu M, Zhao $Y$, et al. Structure of Mpro from COVID-19 virus and discovery of its inhibitors. bioRxiv. 2020.

https://doi.org/10.1101/2020.02.26.964882

18. Walls AC, Park Y-J, Tortorici MA, Wall A, McGuire AT, Veesler D. Structure, function, and antigenicity of the SARS-CoV-2 spike glycoprotein. Cell. 2020. https://doi.org/10.1101/2020.02.19.956581

19. Wang J, Wen J, Li J, Yin J, Zhu Q, Wang $\mathrm{H}$, et al. Assessment of immunoreactive synthetic peptides from the structural proteins of severe acute respiratory syndrome coronavirus. Clinical Chemistry. 2003;49(12):1989-96. https://doi.org/10.1373/clinchem.2003.023184 PMid:14633869 PMCid:PMC7108193

20. Devaux CA, Rolain J-M, Colson P, Raoult D. New insights on the antiviral effects of 
chloroquine against coronavirus: what to expect for COVID-19? International journal of antimicrobial agents. 2020:105938. https://doi.org/10.1016/j.ijantimicag.2020.1059 $\underline{38}$

PMid:32171740 PMCid:PMC7118659

21. Cascella M, Rajnik M, Cuomo A, Dulebohn SC, Di Napoli R. Features, evaluation and treatment coronavirus (COVID-19). Statpearls [internet]: StatPearls Publishing; 2020.

22. Angeletti S, Benvenuto D, Bianchi $M$, Giovanetti M, Pascarella S, Ciccozzi M. COVID-2019: the role of the nsp2 and nsp3 in its pathogenesis. Journal of medical virology. 2020.

https://doi.org/10.1002/jmv.25719

PMid:32083328 PMCid:PMC7228367

23. Asselta R, Paraboschi EM, Mantovani A, Duga S. ACE2 and TMPRSS2 variants and expression as candidates to sex and country differences in COVID-19 severity in Italy. 2020.

https://doi.org/10.2139/ssrn.3559608

24. Dhama K, Sharun K, Tiwari R, Dadar M, Malik YS, Singh KP, et al. COVID-19, an emerging coronavirus infection: advances and prospects in designing and developing vaccines, immunotherapeutics, and therapeutics. Human Vaccines \& Immunotherapeutics. 2020:1-7. https://doi.org/10.1080/21645515.2020.173522 $\underline{7}$

PMid:32186952 PMCid:PMC7103671

25. Wan Y, Shang J, Graham R, Baric RS, Li F. Receptor recognition by the novel coronavirus from Wuhan: an analysis based on decade-long structural studies of SARS coronavirus. Journal of virology. 2020;94(7). https://doi.org/10.1128/JVI.00127-20

PMid:31996437 PMCid:PMC7081895

26. Chen Y, Liu Q, Guo D. Emerging coronaviruses: genome structure, replication, and pathogenesis. Journal of medical virology. 2020;92(4):418-23.

https://doi.org/10.1002/jmv.25681

PMid:31967327 PMCid:PMC7167049
27. Shereen MA, Khan S, Kazmi A, Bashir N, Siddique R. COVID-19 infection: origin, transmission, and characteristics of human coronaviruses. Journal of Advanced Research. 2020.

https://doi.org/10.1016/j.jare.2020.03.005

PMid:32257431 PMCid:PMC7113610

28. Kakodkar P, Kaka N, Baig M. A Comprehensive Literature Review on the Clinical Presentation, and Management of the Pandemic Coronavirus Disease 2019 (COVID19). Cureus. 2020;12(4). https://doi.org/10.7759/cureus.7560 PMid:32269893 PMCid:PMC7138423

29. Bushmaker T, Morris D, Holbrook M, Gamble A, Williamson B, Tamin A, et al. Aerosol and Surface Stability of SARS-CoV-2 as Compared with SARS-CoV-1. The New England journal of medicine. 2020.

30. Rasmussen SA, Smulian JC, Lednicky JA, Wen TS, Jamieson DJ. Coronavirus Disease 2019 (COVID-19) and Pregnancy: What obstetricians need to know. American journal of obstetrics and gynecology. 2020. https://doi.org/10.1016/j.ajog.2020.02.017

PMid:32105680 PMCid:PMC7093856

31.Kakimoto K, Kamiya H, Yamagishi T, Matsui $T$, Suzuki $M$, Wakita $T$. Initial investigation of transmission of COVID-19 among crew members during quarantine of a cruise ship-Yokohama, Japan, February 2020. Morbidity and Mortality Weekly Report. 2020. https://doi.org/10.15585/mmwr.mm6911e2

PMid:32191689

32.Mukhtar F, Mukhtar N. Coronavirus (COVID-19): Let's Prevent Not Panic. Journal of Ayub Medical College Abbottabad. 2020;32(1):141-4.

33. Wu YC, Chen CS, Chan YJ. The outbreak of COVID-19: An overview. J Chin Med Assoc. 2020;83(3):217-20. https://doi.org/10.1097/JCMA.00000000000002 $\underline{70}$

PMid:32134861 PMCid:PMC7153464 
34. Shen C, Wang Z, Zhao F, Yang Y, Li J, Yuan J, et al. Treatment of 5 critically ill patients with COVID-19 with convalescent plasma. Jama. 2020;323(16):1582-9. https://doi.org/10.1001/jama.2020.4783 PMid:32219428 PMCid:PMC7101507

35. Mecenas $\mathrm{P}$, Bastos $\mathrm{R}$, Vallinoto $\mathrm{A}$, Normando D. Effects of temperature and humidity on the spread of COVID-19: A systematic review. medRxiv. 2020. https://doi.org/10.1101/2020.04.14.20064923

36. Guan W-j, Ni Z-y, Hu Y, Liang W-h, Ou $\mathrm{C}-\mathrm{q}, \mathrm{He} \mathrm{J}-\mathrm{x}$, et al. Clinical characteristics of coronavirus disease 2019 in China. New England journal of medicine. 2020. https://doi.org/10.1101/2020.02.06.20020974

37. Eccles R. Understanding the symptoms of the common cold and influenza. The Lancet infectious diseases. 2005;5(11):718-25. https://doi.org/10.1016/S1473-3099(05)70270$\mathrm{X}$

38. Wang D, Hu B, Hu C, Zhu F, Liu X, Zhang J, et al. Clinical characteristics of 138 hospitalized patients with 2019 novel coronavirus-infected pneumonia in Wuhan, China. Jama. 2020;323(11):1061-9. https://doi.org/10.1001/jama.2020.1585

PMid:32031570 PMCid:PMC7042881

39. Moein ST, Hashemian SM, Mansourafshar B, Khorram-Tousi A, Tabarsi P, Doty RL, editors. Smell dysfunction: a biomarker for COVID-19. International Forum of Allergy \& Rhinology; 2020: Wiley Online Library. https://doi.org/10.1002/alr.22587

PMid:32301284 PMCid:PMC7262123

40. Gautier JF, Ravussin Y. A New Symptom of COVID-19: Loss of Taste and Smell. Obesity.2020.https://doi.org/10.1002/oby.22809 PMid:32237199 PMCid:PMC7228286

41. Lim J, Jeon S, Shin H-Y, Kim MJ, Seong YM, Lee WJ, et al. Case of the index patient who caused tertiary transmission of COVID-19 infection in Korea: the application of lopinavir/ritonavir for the treatment of COVID-
19 infected pneumonia monitored by

quantitative RT-PCR. Journal of Korean medical science. 2020;35(6). https://doi.org/10.3346/jkms.2020.35.e79 PMid:32056407 PMCid:PMC7025910

\section{Ai T, Yang Z, Hou H, Zhan C, Chen C, Lv}

$\mathrm{W}$, et al. Correlation of chest CT and RT-PCR testing in coronavirus disease 2019 (COVID19) in China: a report of 1014 cases. Radiology. 2020:200642.

https://doi.org/10.1148/radiol.2020200642

PMid:32101510 PMCid:PMC7233399

43. Cheng Z, Lu Y, Cao Q, Qin L, Pan Z, Yan $\mathrm{F}$, et al. Clinical features and chest CT manifestations of coronavirus disease 2019 (COVID-19) in a single-center study in Shanghai, China. American Journal of Roentgenology.2020:1-6.

https://doi.org/10.2214/AJR.20.22959

PMid:32174128

44. Li Z, Yi Y, Luo X, Xiong N, Liu Y, Li S, et al. Development and clinical application of a rapid IgM-IgG combined antibody test for SARS-CoV-2 infection diagnosis. Journal of medical virology. 2020. https://doi.org/10.1002/jmv.25727

PMid:32104917 PMCid:PMC7228300

45. Zhang Y, Odiwuor N, Xiong J, Sun L, Nyaruaba RO, Wei H, et al. Rapid Molecular Detection of SARS-CoV-2 (COVID-19) Virus RNA Using Colorimetric LAMP. medRxiv. 2020.

https://doi.org/10.1101/2020.02.26.20028373

46. Li H, Liu S-M, Yu X-H, Tang S-L, Tang C-K. Coronavirus disease 2019 (COVID-19): current status and future perspective. International Journal of Antimicrobial Agents. 2020:105951.

https://doi.org/10.1016/j.ijantimicag.2020.1059 51

PMid:32234466 PMCid:PMC7139247

47. Jin Y-H, Cai L, Cheng Z-S, Cheng H, Deng T, Fan Y-P, et al. A rapid advice guideline for the diagnosis and treatment of 2019 novel coronavirus (2019-nCoV) infected 
pneumonia (standard version). Military Medical Research.2020;7(1):4. https://doi.org/10.1186/s40779-020-0233-6

PMid:32029004 PMCid:PMC7003341

48. Li G, Fan Y, Lai Y, Han T, Li Z, Zhou P, et al. Coronavirus infections and immune responses. Journal of medical virology. 2020;92(4):424-32.

https://doi.org/10.1002/jmv.25685

PMid:31981224 PMCid:PMC7166547

49. Deng X, van Geelen A, Buckley AC, O'Brien A, Pillatzki A, Lager KM, et al. Coronavirus endoribonuclease activity in porcine epidemic diarrhea virus suppresses type I and type III interferon responses. Journal of $\quad$ virology.2019;93(8):e02000-18.

https://doi.org/10.1128/JVI.02000-18

PMid:30728254 PMCid:PMC6450110

50. Keicho N, Itoyama S, Kashiwase K, Phi NC, Long HT, Van Ban V, et al. Association of human leukocyte antigen class II alleles with severe acute respiratory syndrome in the
Vietnamese population. Human immunology. 2009;70(7):527-31.

https://doi.org/10.1016/j.humimm.2009.05.006 PMid:19445991 PMCid:PMC7132661

51. Xu Z, Shi L, Wang Y, Zhang J, Huang L, Zhang $C$, et al. Pathological findings of COVID-19 associated with acute respiratory distress syndrome. The Lancet respiratory medicine.2020;8(4):420-2. https://doi.org/10.1016/S2213-2600(20)30076$\underline{X}$

52. Huang C, Wang Y, Li X, Ren L, Zhao J, $\mathrm{Hu} \mathrm{Y}$, et al. Clinical features of patients infected with 2019 novel coronavirus in Wuhan, China. The Lancet. 2020;395(10223):497-506. https://doi.org/10.1016/S0140-6736(20)30183$\underline{5}$

How to Cite: Dorgaleleh S, Miri N S, Hajimohammadi Z, hosravi-bachehmir F, Vahidi A, Oladnabi M. Emerging SARS-Cov-2 Infection in a Rapidly Changing World. jcbr. 2020; 4 (3) :15-27 